\title{
LAS NORMAS JURÍDICAS Y LAS POLÍTICAS PÚBLICAS SOBRE BOSQUES CULTIVADOS EN LAS REGIONES DEL CENTRO Y DE PATAGONIA EN ARGENTINA
}

\author{
MINAVERRY, C. M. ${ }^{1}$;
}

\begin{abstract}
RESUMEN
El eje central de este trabajo es analizar el nivel de desarrollo de las normas jurídicas, de las políticas públicas, y de la idoneidad de las autoridades de aplicación sobre bosques cultivados, en las regiones del Centro y de la Patagonia en Argentina. Se trata de una investigación de carácter exploratorio, donde se aplicó el método de la hermenéutica jurídica y los indicadores ambientales PER. Se puede concluir que los niveles de desarrollo normativo de las provincias no son uniformes, y que la mayoría de las normas jurídicas y de las políticas públicas tienden a establecer incentivos económicos para aprovechar el efecto del mercado, sin orientarse hacia una protección integral de los ecosistemas boscosos, y que las autoridades de aplicación en su mayoría no son técnicamente adecuadas para eso.
\end{abstract}

Palabras clave: Bosques, Derecho Ambiental, políticas públicas, Argentina, indicadores ambientales PER.

\begin{abstract}
Planted forests regulations and public policies at the center and Patagonian regions in Argentina.

The core idea of this paper is to analyse the development levels of regulations, public policies and of application's authorities' suitability in connection with planted forests at the Centre and Patagonian regions in Argentina. This is an exploratory research, where legal hermeneutics and environmental PER indicators were applied. We can conclude that provincial regulations development levels are not even, and that the majority of regulations and of public policies are focused on fixing economic incentives in order to take advantage of market's effect, without focusing on an overall forests ecosystem protection, and that application's authorities are not technically suitable for this.
\end{abstract}

Key words: Forests, Environmental Law, public policies, Argentina, PER environmental indicators.

1.- CONICET. Instituto de investigaciones Ambrosio Gioja, Facultad de Derecho, Universidad de Buenos Aires. Av. Figueroa Alcorta 2263. $1^{\circ}$ piso. Ciudad Autónoma de Buenos Aires, Argentina. Email: cminaverry@derecho.uba.ar Departamento de Ciencias Sociales, Universidad Nacional de Luján. Email: cminaverry@mail.unlu.edu.ar Manuscrito recibido el 11 de febrero de 2017 y aceptado para su publicación el 3 de julio de 2017. 